\title{
Reasoning changes of commercial sex workers in Mount Kemukus area from hedonistic to religious reasoning through moral education
}

\author{
Nasri Kurnialoh ${ }^{1}$, Muhammad Miftah ${ }^{2}$ \\ STAI Haji Agus Salim Cikarang Bekasi ${ }^{1}$, Institut Agama Islam Negeri (IAIN) \\ Kudus $^{2}$ \\ nasri_kurnialloh12@yahoo.co.id ${ }^{1}$, muhammadmiftah@stainkudus.ac.id ${ }^{2}$ \\ DOI: $10.18326 /$ attarbiyah.v4i2.167-183
}

\begin{abstract}
The main problem of this research is the sociological aspects of commercial sex workers (CSW) in Mount Kemukus. This study will focus on sociological forms and patterns in Mount Kemukus community from the aspect of family, social, and work environment, as well as religious activities among CSW in Mount Kemukus. This study also examines the mindset of CSW who are more inclined towards hedonistic life. As a result of this mindset, they are willing to plunge themselves into the practice of prostitution wrapped in pesugihan rituals. The forms and patterns of social interaction of CSW carried out in the sociological environment have experienced various problems, both those that are associative and those that are dissociative with the conditions in society. As for the aspects of religious activities of CSW who adhere to Islam, it shows that most of them no longer carry out the commands of Islamic teachings. One thing they know, namely the hedonist lifestyle with the fastest way to get money to meet the needs of themselves and their families, namely by working as a prostitute in the Kemukus Mountain environment.
\end{abstract}

Keywords: Sociological, Hedonism, Religious, Moral Education 
Attarbiyah: Journal of Islamic Culture and Education

https://www.attarbiyah.iainsalatiga.ac.id/index.php/attarbiyah/

\section{INTRODUCTION}

Localization is a restriction on a particular and special place, in the form of area or scope, limiting the spread of disease, and determining a location with the existence of Commercial Sex Workers (CSW) carrying out their profession in order to maintain their economic life. Today localization is very well known by the people of Indonesia as a place to live/home for Commercial Sex Workers (CSW), and the community in general gives a negative stigma to the existence of this profession. For example, this profession is considered as community rubbish, household destroyers, and is perceived as residents of the black area. Localization develops together with rapid population growth, especially from urbanization and migration from other regions or cities.

Commercial sex workers or prostitutes are women who have the habit of having sexual relations outside of marriage (marital), whether in return for services or not. Prostitution or prostitution is essentially sexual behavior that changes partners, can be done by men and women.

In Indonesia, the practice of prostitution is mostly done by women, although it cannot be denied that the practice of prostitution by men began, there are also many practices of prostitution along the cross-city lines. The main reason for someone to go into the practice of prostitution is usually motivated by economic problems; because of limited education and demoralizing behavior they see prostitution as both a work and a profession that is very promising to earn a lot of money.

The most determining factor for a person's involvement in the practice of prostitution is economic pressure. In the era of rapid development towards an industrial country, competition for a good living is very much determined by one's level of education. The competitiveness of a person with a higher education is certainly stronger than those with a low education, in addition to the increasingly limited area of employment. 
The moral crisis and hedonist lifestyle have had a systemic impact on people's lives, this certainly led to a shortcut to get money as a commercial sex worker (CSW) even though it was against religious teachings and moral values that prevailed in society.

\section{DISCUSSION}

\section{Moral education}

Moral education is learning or teachings about habits and procedures for behavior (Hurlock, 1978: 74). Moral education is considered to be the same as teaching various kinds of rules and character development, which are expected to be seen in behavior that shows good qualities that are traditionally visible in behavior such as honesty, self-mastery, courage, hospitality, and respect (Duska \& Whelan, 1982: 15).

There are two important factors in moral education, namely internal factors (within the individual itself) and external factors in the form of the social environment, especially the family (Googde, 2007: 20). So moral education is learning about habits or procedures for behaving in accordance with applicable rules or traditions.

\section{The Purpose of Moral Education}

The purpose of moral education is to inculcate good qualities so that they become inner principles which become demands for behavior and demands in making decisions (Dwija, 1982: 15).

According to Frankena the objectives of moral education are five, namely: First, to seek an understanding of "moral views" or moral ways in considering actions and determining what decisions should be done, such as distinguishing aesthetics, legality, or views on wisdom. Second, it helps develop trust or adoption of one or several general principles that are fundamental, ideas, or values as a platform or basis for moral considerations in setting a decision. Third, help develop trust in and or adopt concrete norms, values, virtues as in traditional moral education that has been practiced so 
far. Fourth, develop a tendency to do things that are morally good and right. Fifth, increasing the achievement of autonomous reflection, self-control or mental and spiritual freedom, even though it is realized can make a person a critic of ideas and principles, and general rules that are in force (Tilaar, 1990: 365).

Based on these goals, the purpose of moral education in the family is to instill the values of moral virtue so that students are easier to socialize and make it a true principle of life.

\section{Moral Education Material}

Broadly speaking, the scope of moral education material can be grouped into three moral values, namely as follows: morals towards God Almighty, morals towards fellow human beings, and morals towards the environment (Zuriah, 2007: 27).

\section{Moral Educator}

Educators must have a good personality, and can be an example, some personality traits that must be owned by the teacher / educator, among others. First, the teacher must be devoted to God Almighty with all the qualities, attitudes, and practices that reflect his piety. Second, the teacher must be sociable, especially associating with children. Third, the teacher is a person who is full of interest, caring, loves his profession and work, and tries to develop and improve his profession so that his teaching ability is better. Fourth, the teacher is a person who likes to learn continuously, even though he is an identical educator who transmits knowledge and spreads insights, but must also be an educated person who is always learning new things (Mu'in, 2011: 350).

\section{Moral Education Method}

The moral education method proposed by Santhut (Shanthut, 1998: 85):

a. Exemplary, is the best method in moral education. Exemplary always requires a consistent and continuous attitude both in actions or noble character. Modeling is still limited to both parents until the child is able to 
walk and begin to get acquainted with relatives, relatives, and close neighbors;

b. By Giving Guidance, it is important to bloom the hearts of students. Because the heart cannot bloom unless it has a value that can be used as a parameter of all its actions and those of others;

c. With the Story of History, in the story of the prophets there are many moral teachings which are explained through the story method;

d. Giving Encouragement and Instilling Fear in God;

e. Fostering Conscience, moral education will not achieve its goals without the application of conscience, which is a strength within human beings, which can judge the merits of an action.

\section{Implementation of Moral Education Method}

a. Value inclusion

Inculcation or investment in values has characteristics (Kartono, et al., 2002: 62):

1) Communicating trust along with the underlying reasons;

2) Treat people fairly;

3) Respect the views of others;

4) Expressing doubt or feeling of unbelief accompanied by reason and with respect;

5) Does not fully control the environment to increase the likelihood of the delivery of desired values and prevent the possibility of delivery of undesirable values;

6) Creating social and emotional experiences about desired values in an extreme manner;

7) Making the rules of giving, giving awards, and giving consequences along with reasons;

8) Keep open communication with parties who do not agree;

9) Give freedom to the existence of different behaviors if to an unacceptable level, directed to provide the possibility of change. 
b. Exemplary Value

There are two conditions for exemplary values that must be met, namely: First, educators or parents must act as good models for students. Second, students must emulate famous people who have noble character, for example the Prophet Muhammad. Teachers and parents in using the exemplary value method must have assertive skills, namely the skills to openly open opinions by not hurting other people's feelings (Tasmara, 2002: 196).

c. Value Facilitation

Facilitation is a way to provide facilities with the aim of training subjects to overcome problems that arise in students. Kirschenbaum argues that in implementing facilitation methods can have a positive impact on personality development as follows (Zuchdi, 2008: 48).

1) Facilitation activities can significantly improve the relationship between educators and students;

2) Facilitation activities help students clarify understanding. The activity provides the opportunity for students to form their opinions, recall things that need to be listened to, and clarify things that are still doubtful;

3) Facilitation activities help students receive a value, but have not consistently practiced it, increasing from an intellectual understanding of the commitment to act;

4) Facilitation activities help students think further about the values learned, find their own insights, learn from friends who have received grades;

5) Facilitation activities cause educators to better understand the thoughts and feelings of students;

6) Facilitation activities motivate students to connect problems of values with their own lives, beliefs and feelings. 
d. Ability to develop moral values.

Skills in developing moral values are indirect methods by providing opportunities and skills for students to become independent, constructive, effective decision makers, and to become good citizens. These skills include listening skills, acting assertively, and finding conflict resolution in a concise manner (Ali, 2007: 93).

\section{Commercial Sex Workers in Sociological Perspective}

Sociologically, deviant behavior is behavior that is considered to violate the values and norms prevailing in society. Behavior like this occurs because someone ignores the norm or does not comply with standard standards in society so that it is often associated with negative terms. This is a disease of the community which can ultimately destroy public trust (Waluya, 2007: 90).

In sociology there are various theories that discuss deviant behavior, namely the Anomie Theory, Differential Associations, Control Theory, and Labeling Theory (Murdiyatmoko, 2007: vi.).

Some theories of social deviance in the sociological approach related to CSW are as follows.

a. Anomie Theory

The problem of CSW can be examined using anomie theory by Robert K. Merton, whose theory departs from the concept of anomie put forward by Emile Durkheim, who argues that anomie is a condition without norms ( deregulation) in society which then gives rise to deviation behavior (Maliki, 2012 : 115).

Anomie theory assumes that deviations are the result of various tensions in a social structure so that there are individuals who experience pressure and end up doing deviant actions.

Included in the deviant category is the phenomenon of "commercial sex workers" who are part of a society that cannot use legitimate goals, methods, means and opportunities to achieve goals. The only visible goal is simply to get a job in order to make money that can be 
used for living expenses and other needs. That is one thing that causes prostitution to flourish and become a choice in these troubled times.

b. Differential Association Theory

Differential association is a theory that studies all behaviors in interactions with others through communication processes, where an important part of studying criminal behavior occurs in intimate groups (Henslin, 2007: 152).

According to Sutherland, deviant behavior carried out by someone is actually the result of the learning process. The process of learning an attitude and action especially from subcultures or among deviant peers (Hong, 2011: 49).

Sutherland also argues that deviant behavior stems from differential association (different relationships) (Maryati \& Suryawati, 2001: 122.). The prostitutes will "pursue" then become "experts" in their activities because through a learning in the form of channels with deviant sexual behavior. This is in the form of customers who can be said by the media for CSW to learn more about the role of sex workers.

c. Control Theory

Social control is often interpreted as an oversight by the community on the course of government, especially the government and its officials. This aims to achieve harmony between stability and changes in society and to achieve a state of peace through harmony between certainty with justice or equality (Soekanto, 1989: 170).

The background of control theory is that deviations are the result of a control vacuum. This theory is built on the view that every human being tends to disobey the law or have the urge to violate the law.

d. Labeling Theory

According to Becker, deviations are a consequence of applying rules and sanctions by others to a violator. This is meant that deviations are actions that are labeled to someone or to whom the label has been specifically set, so that the benchmarks of deviations are determined not 
based on the norm or quality of the action but through the reaction of the community (Bagong, 2011: 57).

The analysis of labeling or stamping focuses on people's reactions, which means there are people who give definitions, nicknames or labelers to individuals or actions which according to the person's judgment are negative.

Giving a distorted label will result in a distorted social role as well. That is, with a stamp attached to a person who is given the stamp tends to develop a distorted self-concept.

For example someone who behaves as a homosexual for money, even though the action was carried out by force. However, because the community has already labeled it as a reaction to his actions, then as a result he will become a real homosexual.

CSW need social encouragement to get out of their lives to become people who are sociable and have good morals. All that can not happen without the help of positive perceptions to embrace them and get out of their black world.

This perspective confirms that making ex-sex workers can get out of their dark world with encouragement and hope morally from the community. The matter explained above concludes that CSW can fall into and out due to the dramaturgy process in society that turns into material and economy into number one by selling everything that exists and with the hope that other people so that CSW out of the world who sell themselves can make CSW have have a better life.

\section{Urgency of Religious Education for Changing Hedonistic Reason to Religious Reasoning of Commercial Sex Workers (CSW) in Mount Kemukus Area}

Religion is the basic basis for welcoming and preparing an ideal, harmonious, loving and understanding family that includes the child. In this case the role of education as an effort to foster children that leads to the 
implementation of the inculcation of religious values is very important for the development of children, especially in forming a religious (Islamic) generation.

Constitutionally determined that the Indonesian state is based on religion. As a state based on religion, religious education cannot be ignored in the administration of national education (Asrohah, 2001: 181).

Religious education not only teaches religious knowledge and trains children's skills in carrying out worship. But religious education is far broader than that which concerns the whole person. Therefore, religious education will be more memorable and effective and effective, if the entire environment that contributes to the personal development of children (family, school and community) together leads to the fostering of the soul of religion in children (Daradjat, 1970: 107 ) .

Education is something that is essential for humans, especially for the development of children into adulthood. Through education, a child can learn to face the universe in order to maintain his life. Because of the importance of education, Islam places education in an important and high position in Islamic doctrine. This can be seen in the Qur'an and hadith which explain a lot about the meaning of education for the lives of Muslims as servants of Allah.

In the Qur'an, it is stressed that Allah created man to make the final goal or the result of all his activities as a devotion to Him (Hud: 61). In this verse the "activities" intended by Allah SWT are contained in the Al-Quran which confirms that humans are the Khalifah of Allah (al-Baqarah: 30). In its status as caliph, humans have the task of Allah SWT that is to prosper or build this earth in accordance with the concepts established by Allah SWT (Shihab, 1992: 172 ).

God's revelation contained in the Al-Quran encourages Muslims to gain knowledge and be able to distinguish between human beings and objects as well as the natural surroundings. In this case the teachings of Islam encourage humans to respect reason, so as to provide motivation and try to 
seek knowledge wherever located. The importance of science to humanity is explained in QS al-Mujadilah [58]: 1.

So, religious education is an effort to strengthen faith and piety in Allah SWT, with the aim that early students can understand, live and practice religious teachings in accordance with their personal growth, as a provision for future life with the hope that the child will be able to develop his potential .

Humans are beings who always long for perfection, so that with all the potential it has, it tries to progress and develop to reach its perfection both physically and spiritually.

In order to fulfill that need, it is demanded to associate with other people and the universe that is always changing, so that they can adapt to the environment and maintain their lives. Business success is highly dependent on the role of education, especially religious education in instilling religious values in one's person.

Education is recognized as a power that can determine one's achievement and productivity. With the help of education, a person can understand and interpret the environment that he faces, so that he is able to create a brilliant work in his life. Or he can reach a high civilization (Asrohah, 2001: 2. ).

The fact that in religious life or referred to as religious communities, the actualization of religious actualization, namely religious education in instilling religious values has not been able to display its full role in social life. So it is necessary to emphasize from all parties in guiding and educating generations to a practical level, in this case there is an intensive coaching step.

The importance of religious education for children was first carried out in family, community and state life. Religious education in the family is very dominant for the development of children's lives. Therefore, the role of both parents in educating, maintaining and providing supervision to children is quite significant in shaping children's behavior and attitudes in a positive direction. In the process of development, the child will accept whatever is said by his parents. According to children, parents are always right, powerful, smart, 
and decisive. Then the relationship between parents and children will have a great influence on religious education for children.

Perhaps it is difficult to ignore the role of the family in education. children from infancy to school age have a single environment, that is the family. So what has been done or habits possessed by children is largely formed through family education ( Rachmat, 2001: 215. ).

Family education is the basic education for the formation of religious souls. In this case the role and function of parents are even able to shape the direction of their children's beliefs, but the form of religious beliefs adopted by children depends on the guidance, care and influence of their parents ( Daradjat, 1970: 56-59. ).

\section{Efforts for Changing Hedonistic to Religious Reasoning of Commercial Sex Workers (CSW) in Mount Kemukus Area}

Sex in Islam is an urgent and crucial issue, it is close to the exchatological future dualism between heaven and hell. Islamic cosmology provides an illustration of how human creation is so detailed and complex, it is clearly told in the scriptures. The Qur'an uses symbolic translation to explain sexual conceptions in terms of cosmological themes, how humans were created from nuthfah (semen), into blood clots, clots of flesh, blown by spirits, and so on.

The implementation of the role of religion and moral education in the prevention of the practice of prostitution, in the view of religion and customs of various tribes in Indonesia all reject the desecration of the practice of prostitution, for example in Islam, the prohibition of adultery, the word of God in QS al-Isra '[17]: 32.

On the other side nationally, the government has not agreed on how to tackle the practice of prostitution even in the Criminal Code there is not a single article specifically prohibiting people from prostituting themselves in the context of sex commercialization, which is prohibited and threatened with crime is the practice of pimp (Article 296 of the Criminal Code), intercourse 
with minors (Article 287) pimps (Article 506 of the Criminal Code) and marriage (Article 284), regarding that marriage is even more offense.

In connection with the foregoing, there needs to be a role for religion and moral education as social institutions that provide a set of rules that must be followed by every adherent to the consistency and consequences of every person in religion must be maintained in any condition, especially regarding the prohibition. The religion of Islam was revealed to the world to contain ideal universal ethical values, which regulate not only the relationship to God, but also contains the rules of human practice.

Religious attitudes are the attitudes of individuals in following and carrying out the commands of their religion. Religious attitudes become interesting, if viewed from the applicative side of people who work as commercial sex workers (CSW).

One side they have received religious lessons at least from the environment where they lived before that requires them to carry out religious orders, and the other side they are required to make a living by doing acts that are contrary to religious teachings. Of course there are various efforts made so that they gradually gain understanding and mental and spiritual strengthening to end their profession such as through religious counseling.

In this context, religious education and moral education activities around the prostitution environment are very important for the local community, including commercial sex workers (CSW) who inhabit prostitution.

Some steps that can be taken to foster religious life in children can be divided into two kinds of guidance and teaching, namely guidance and teaching individually and in groups:

a. Individual guidance and teaching

1) Modeling

Someone likes to imitate the behavior of people who are older than him. According to education experts give lessons to students through examples or examples more solid and deep impression, is like 
painting on a stone. Children have a strong urge to imitate the behavior, ways of doing and ways of speaking of parents. With exemplary, positive identification symptoms arise, this is very important to shape the child's personality. Because the values that are known to children are still attached to people who are loved and admired, both by their fathers, mothers and teachers (Marimba, 1989: 85 ).

The cultivation of God experience through an emphasis on satisfying affective needs is very important. Parents and other family members need to create situations and conditions that reflect that God is merciful, merciful, protective and so forth. This can be reflected in the attitudes of parents and society. With the properties above because students will feel directly from these qualities. So to give a picture that God has a set of main and noble qualities is not difficult.

Abdullah Nashih Ulwah states that the example is an important factor in the formation of a person's good or bad. If educators have an honest, noble, brave, forgiving nature, students will grow to be honest, noble, brave, and forgiving. However, if the educator has the nature of a liar, a traitor, misbehaving, then the child will be a person who likes to lie, betrayed and gripe (Ulwan, 1981: 2. ).

2) Development of religious nature

Since birth children bring religious nature. This fitrah only functions after going through the process of guidance and training. Basically, humans are prepared by God as servants, caliphs, social beings, paired creatures and unique creatures. The initial potential has been prepared by the Creator with all the potential needed when humans actually live as humans in society, as explained in QS ar-Rum [30]: 30.

The verse shows that humans were created by bringing fitrah (religious potential) that is Hanif, true and cannot avoid. Although he ignores or does not admit psychologically every weak, small and limited need stronger protection. Therefore, when humans as weak creatures 
are in a position of being threatened, cornered and there is no way out in them arises a mighty hope, a great one who is expected to help him out of a situation of helplessness.

In line with the opinion of Ibn Kathir in his interpretation, that this verse contains the meaning of Allah SWT inspires the soul of his ungodliness and devotion, namely pointing it to something that can lead to his ungodliness and devotion (Syihabuddin, 2000: 89 ).

The nature that Allah SWT has created in every human being will show the truth and goodness. He still voiced a call to always return to divine truth. However bad a person's behavior is, their consciences remain alive and are able to distinguish between the bad and the right. In the development and growth of humans from birth to adulthood, nature is often not a concern so that he cannot participate in every word and deed. Herein lies the importance of proper training and guidance.

\section{CONCLUSION}

Sociogenetically, the decision to become CSW in Mount Kemukus area in addition to the factors mentioned above, is also influenced by environmental conditions around them (suggestive), such as weak personalities and lacking skills, so that feelings emerge quickly to imitate, feelings of envy towards peers whose status as prostitutes are more successful in the economic field (prostitute models that have been successful), there are invitations from the environment both friends or people who claim success with the CSW profession.

The change and formation of Hedonistic Reasoning to religious reasoning through moral education is carried out as an effort to restore the condition and life of Commercial Sex Workers (CSW) in the Mount Kemukus area towards a good life and in harmony with religious norms and moral rules in society. 
Attarbiyah: Journal of Islamic Culture and Education

https://www.attarbiyah.iainsalatiga.ac.id/index.php/attarbiyah/

\section{REFERENCES}

Ali, Mohammad. (2007). Ilmu dan Aplikasi Pendidikan Bagian 1. Bandung: IMTIMA.

Asrohah, Hanun. (2001). Sejarah Pendidikan Islam. Jakarta: Logos Wacana Ilmu.

Bagong, J. Dwi Narwoko. (2011). Sosiologi: Pengantar dan Terapan. Jakarta: Kencana.

Daradjat, Zakiah. (1970). Ilmu Jiwa Agama. Jakarta: Bulan Bintang.

Depag RI. (2005). Al-Qur'an dan Terjemah. Jakarta: Gema Insani.

Duska, Ronald dan Mariellen Whelan. (1982). Perkembangan Moral, terj. Dwija Atmoko. Yogyakarta: Kanisius.

Dwija, Atmoko. (1982). Perkembangan Moral. Yogyakarta: Kanisius.

Googde, William J. (2007). Sosiologi Keluarga, terj. Lailahanoum Hasyim. Jakarta: Bima Aksara.

Henslin, James M. (2007). Sosiologi dengan Pendekatan Membumi Jilid 1. Jakarta: Erlangga.

Hong, Zicheng. (2011). Roots of Wisdom: Inti Kebijakan. Bandung: Grafindo.

Hurlock, Elizabeth B. (1978). Perkembangan Anak, terj. Meitasari Tjandra. Jakarta: Erlangga.

Kartono, dkk. (2002). Pendidikan Budi Pekerti di Sekolah. Yogyakarta: Kanisius.

Maliki, Zainuddin. (2012). Rekonstruksi Teori Sosial Modern. Yogyakarta: UGM Press.

Marimba, Ahmad D. (1989). Pengantar Filsafat Pendidikan Islam. Bandung: Alma'arif. 
Maryati, Kun dan Juju Suryawati. (2001). Sosiologi Jilid 1 untuk SMA dan MA. Jakarta: Erlangga.

Mu'in, Fathul. (2001). Pendidikan Karakter: Teoritik dan Paraktik. Jogjakarta: ArRuzz Media.

Murdiyatmoko, Janu. (2007). Sosiologi: Memahami dan Mengkaji Masyarakat. Bandung: Grafindo.

Rakhmat, Jalaludin. (2001). Psikologi Agama. Jakarta: RajaGrafindo Persada.

Shanthut, K.A. (1998). Menumbuhkan Sikap Sosial, Moral, dan Spiritual. Yogyakarta: Pustaka Pelajar.

Shihab, M. Quraish. (1992). Membumikan Al-Qur'an: Fungsi dan Peran Wahyu dalam Kehidupan Masyarakat. Bandung: Mizan.

Soekanto, Soerjono. (1989). Suatu Tinjauan Sosiologi Hukum terhadap Masalahmasalah Sosial. Bandung: Citra Aditya Bakti.

Syihabuddin. (2000). Ringkasan Tafsir Ibnu Katsir, terj. Muhammad Nasib arRifa'i. Jakarta: Gema Insani Pers.

Tasmara, Toto. (2002). Membudayakan Etos Kerja Islami. Jakarta: Gema Insani Press.

Tilaar, H.A.R. (1990). Pendidikan dalam Pembangunan Nasional Menyongsong Abad XXI. Jakarta: Balai Pustaka.

Ulwan, Abdullah Nashih. (1981). Pedoman Pendidikan Anak dalam Islam Jilid 2. Bandung: asy-Syifa'.

Waluya, Bagja. (2007). Sosiologi: Menyelami Fenomena Sosial di Masyarakat. Bandung: Setia Purna Inves.

Zuriah, Nurul. (2007). Pendidikan Moral dan Budi Pekerti dalam Perspektif Perubahan. Jakarta: Bumi Aksara. 